\title{
Parasitic Diseases in Dairy Cattle in Cibungbulang District of West Java
}

\author{
Dewi DA ${ }^{1}$, Wardhana $\mathrm{AH}^{1}$, Sawitri $\mathrm{DH}^{1}$, Ekawasti $\mathrm{F}^{1}$, Akbari RA ${ }^{2}$ \\ ${ }^{1}$ Indonesian Research Center for Veterinary Science \\ Jl. RE Martadinata No. 30, Bogor 16114, West Java, Indonesia \\ ${ }^{2}$ Faculty of Veterinary Medicine, Bogor Agriculture University, Jl. Agatis, Dramaga, Bogor \\ diasaprita@gmail.com
}

\begin{abstract}
Cibungbulang District of West Java is a region where has a population of dairy cattle and it has been pointed as one of central livestock comunity (Sentra Peternakan Rakyat, SPR). However, parasitic diseases remains a major problem at the area. The purpose of study was to determine parasitic diseases attacking Friesian Holstein $(\mathrm{FH})$ dairy cattle in the Cibungbulang District of West Java. Examination of stool and blood serum should be done to strengthen the diagnosis of parasitic diseases. A total of 130 blood and faeces was collected. Stool examination was conducted using Withlock method to calculate and observe the egg shape of worms including Eimeria sp. Blood sera examination were carried out for serological tests of Trypanosoma evansi based on Card Aglutination Trypanosomiasis Test (CATT) - T. evansi method. The results showed $36.92 \%$ (48/130) FH cattle were infested by Trichostrongylus spp, $2.31 \%$ (3/130) by Toxocara vitulorum, $20 \%(26 / 130)$ by Eimeria sp and others were negative, 40.77\% (53/130). In addition, $14.62 \%$ (19/130) sera possessed a positive response for CATT test, consisting 6.15\% (8/130) of medium agglutination (+),6.92\% (9/130) of strong agglutination (++) and $1.54 \%$ (2/130) of weak agglutination/dubious $( \pm)$. In conclusion, FH cattle in Cibungbulang District are infested by internal parasites (worms and Eimeria sp) and are positive serologically for T. evansi. In term of management system, farmers should maintain level of environmental sanitation to increase milk production.
\end{abstract}

Key Words: Stool, Serum, Parasites, Dairy Cattle, Cibungbulang

\section{INTRODUCTION}

Dairy cattle are alternatives cattle used to assist farming and procurement of animal protein. Milk and meat production are rapidly rising in order to increase of population, economic growth, improved education levels and farmers's prosperity. To compensate for the level of farm product, the efforts focused on optimizing productivity and reproducibility of livestock, with the ability to suppress the morbidity or mortality of livestock and the spread of disease (Sutama 2008; Santosa et al. 2013).

Livestock industry has been facing various problems, such as parasitic diseases. It should be anticipated to obtain a maximum benefit. According to Munadi (2011), animal diseases may cause considerable economic losses for farmers and they potentially transmit to humans. Dairy cattle are vulnerable livestock for diseases caused by viral infections, bacterial and parasitic nematodes, trematodes, coccidia protozoa, and blood protozoa (Soulsby 1982; Sudarisman 2006).

Cibungbulang District of West Java is a region where has a high population of Friesian Holstein $(\mathrm{FH})$ dairy cattle, In addition, this farm is also a regional farm to supply milk in Bogor and several dairies. The local government intends to develop a dairy farm in the Cibungbulang District by pointing as Sentra Peternakan Rakyat (SPR). To achieve the successful program, identification of livestock diseases occurring in the farm is fundamentally needed to determine a strategy of disease control. Parasitic disease in livestock industry remains a serious problem, including in a dairy cattle industry. In term of parasitic agents, helminthiasis and coccidiosis cause decreasing productivity of 
livestock. They are able to absorb any nutritious food in the digestive tract. In addition, blood protozoan, Trypanosoma evansi has also economic value on livestock management. The CATT- $T$. evansi test is a well validated field assay for the detection of $T$. evansi in camels, buffalo, and cattle. The assay is based on variable surface antigen (VSG) designated as RoTat 1.2 which is thought to be expressed in all $T$. evansi isolates (Desquesnes et al. 2013).

In term of parasitic agent, helminthiasis and coccidiosis remains a major problem in diary cattle. Pathological effects caused by these parasites and weight loss generated by diarrhea lead to unproductive milk yield. It is believed the parasites are able to absorb any nutritious food in the digestive tract, including sucking blood and fluids. In addition, the parasite also helps to produce toxin that may result in clogged arteries and acts as entry point for various pathogenic bacteria or virus into tissues so that stimulate secondary infections (Rahmi et al. 2010; Rajakaruna \& Warnakulasooriya 2011).

Moreover, besides nematode parasites and coccidia gastrointestinal tract, blood parasitic diseases such as Surra also have an economic value causing increased morbidity and mortality of livestock. Surra caused by T. evansi is pathogenic blood parasite which has worldwide distribution. In Indonesia surra outbreaks have been reported in the Sumba Island, in 2010-2012. This condition can be more severe if the disease control is not treated quickly and accurately, because it might be a potential spread of the vulnerable populations in other areas or to another island (Desquesnes et al. 2013). Accordingly, determination parasitic diseases (helminthiasis, coccidiosis, and surra) are needed. The purpose of study was to determine parasitic diseases attacking Friesian Holstein $(\mathrm{FH})$ dairy cattle in the Cibungbulang District of West Java.

\section{MATERIAL AND METHODS}

\section{Sample and location}

A total of 130 sera and faeces of dairy cattle was collected from one of central livestock community (SPR) in Cibungbulang District, Bogor, West Java Province.

\section{Stool sample preparation}

Faeces were collected directly from a rectum of cattle or faeces can be collected from the floor if the catlle just defecated. Each faeces was put into a small plastic bag, labeled and storaged. Faecal samples was investigated at $4^{\circ} \mathrm{C}$ until further analysis. In the laboratory, a stool sample is prepared for counting worm eggs and coccidia.

\section{Counting the number of eggs and coccidia nematode worms}

A total of $3 \mathrm{~g}$ of faeces from each sample was dissolved in $17 \mathrm{ml}$ water for a few minutes, then crushed and added $40 \mathrm{ml}$ saturated salt solution in order to float nematode eggs and coccidia. After that, while the solution stool was stirred stirring, it was sucked using a pipette incorporating the filter and the solution was dropped gently in the room count of Withlock (Withlock 1960). Nematode eggs and coccidia were calculated (room count) under a microscope and the number of eggs was multiplied by 40 . The number of eggs and coccidia are calculated in units of EPG (egg per gram). 


\section{Serum sample preparation}

Serum dairy cattle were collected from jugular vein in the neck area using vacuum tubes, then put in the ice box. Serum which has been separated from the blood were taken using a pipette and put in a volume of $5 \mathrm{ml}$ serum tubes. Each serum tube was labeled and stored at $-20^{\circ} \mathrm{C}$ for serological test.

\section{Serologic test using card agglutination trypanosomiasis test (CATT) - T. evansi}

Serologic examination using Card Aglutination Trypanosomiasis Test (CATT) - $T$. evansi in accordance with the test procedures based sample pieces of work instructions in the kit made by Prof. N Van Meirvenne, Institute of Tropical Medicine, Antwerp, Belgium.

The first stage, making serum solution for 1:8. A total of $20 \mu \mathrm{l}$ serum was diluted in CATT buffer until the volume reached $140 \mu$ l. The second stage, 1 ampoule of $T$. evansi antigen was diluted into $2.5 \mathrm{ml}$ PBS buffer then shaken until homogeneous. Agglutination reaction was performed by dropping the first drop of antigen $( \pm 45 \mu \mathrm{l})$ on each circle on the CATT cardboard and added of $25 \mathrm{ml}$ serum solution, then stirred with a plastic rod until homogeneous. Sample testing one sample to the next, stir bar should be wiped beforehand with a paper "tissue" to avoid contamination between samples tested. The last stage is placed the carton CATT on a rotator with $70 \mathrm{rpm}$ for 5 minutes and the results are read directly visually.

Positive reaction in case of agglutination process is shown in the form of clumps and a negative reaction if no agglutination process. Scores reaction were divided into four categories namely: $(+++)=$ Very strong agglutination, $(++)=$ Strong agglutination, $(+)=$ Medium agglutination, $( \pm)=$ Weak agglutination or dubious, and $(-)=$ No agglutination occurs.

\section{RESULTS AND DISCUSSION}

\section{Stool examination}

The results of stool examination found $36.92 \%$ (48/130) Trichostrongylus spp., $2.31 \%$ (3/130) Toxocara vitulorum and 20\% (26/130) Eimeria sp. The remaining sample were negative (40.77\% ;53/130) from both worms egg and Eimeria sp investigation (Figure 1).

Gastro intestinal parasites of diary cattle in Cibungbulang district (\%)

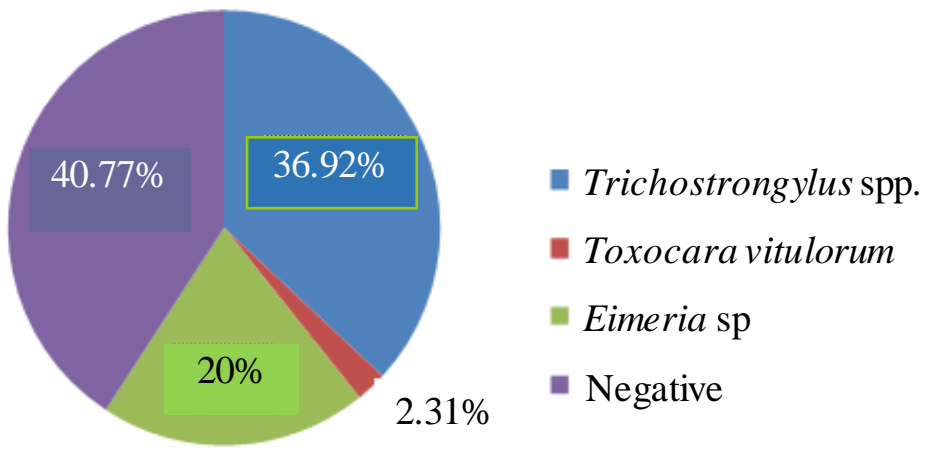

Figure 1. Results of stool examination dairy cattle in Cibungbulang District based on the floatation method 
The worm infecting dairy cattle with IBR infection might cause the host getting severe infection. As a result, the host would be dead eventually. Worm of Trichostrongylus spp is a combination of nematode Haemonchus sp, Trichostrongylus sp and Oesophagostomum sp (Beriajaya \& Nurhadi 1995). The life cycle of the group parasitic nematode Trichostrongylus spp does not require any other animals they only complete their life cycle in a definitive host life. Ruminants infected by swallen larvae 3 (L3). Generally larvae are drawn on ruminants graze and when the larvae enter the digestive tract occurs cuticle solving process. L3 will penetrate the membrane or enter the gastrium glands. For a few days, they will develop into L4 of about 10-14 days. L4 will develop into adult worms and start producing eggs about three weeks after infection (Nezar 2014; Handayani et al. 2015; Purwanta 2012).

The percentage of the results of eggs Toxocara vitulorum is $2.31 \%$. Eggs of $T$. vitulorum are round and thick-walled. T. vitulorum are parasites in the digestive tract of ruminants. The prevalence is higher in the tropics and in young ruminants. Infection occurs during the prenatal and neonatal through colostrum. Adult parasites that live in the small intestine produce prolific egg and a very large number of eggs are produced daily. The eggs have thick walled which are highly resistant to climatic conditions and adverse environments and remain infective for long periods of time (several years) (Satrija et al. 2011; Agustina 2013; Winarso 2015).

Decreasing prevalence in the age group of older cattle is caused by at least three possible causes, namely the cessation of new transmammary infections in calves a few days after birth, the death of the adult worms, and increasing immunity of animals (the host). Transmammary infection is the main route of infection that produces adult worms in the intestines of cattle. Calves receive much more infectious Toxocara larvae when feeding, and these transmamaria plays an important role in the course of the life cycle of Toxocara (Anderson 2000). The development of $T$. vitulorum larvae into adult worms in cattle over the age of 6 months are rarely encountered. Very infrequently eggs found in young cattle and cattle. Death of adult worms may have something to do with the development of immunity of the host.

Coccidia were detected from the faeces of dairy cattle from the Cibungbulang District around $20 \%$. Coccidia in digestive tract of cattle include Eimeria zuernii, E. linoisensis, E. Cylindrical, E. auburnensis, E. Canadensis, E. pellita, E.alabamensis, E. subspheria, and E. bovis. Coccidia is small and looks clear. Coccidia contains sporosista. Each sporosista contains sporozoid. To identify Eimeria what hit dairy cattle in this study must be identified further. Coccidiosis affects many young cattle from age one month to one year (Kertawirawan 2013). The incidence of the disease is usually sporadic during the rainy season, but it is also common during the dry season. The parasite's life cycle begins with the release of oocysts with faeces, then there will be sporulation in 1-2 days (depending on the species and the temperature around). Oocytes have undergone sporulation then ingested by animals, then ooksita broken and formed sporozoites that invade the intestinal mucosa and epithelium. Sprorozoit later developed into schizont, makrogametosit and mikrogametosit. Animals become infected by ingesting infected food oocysts (Jager et al. 2005).

\section{Serology with CATT - T. evansi}

A number of 130 sera of dairy cattle were examined serologically using CATT for $T$. evansi. The result demonstrated that $6.15 \%(8 / 130)$ sample gave a medium agglutination $(+), 6.92 \%$ (9/130) strong agglutination (++) $1.54 \%$ (2/130) weak agglutination/dubious $( \pm)$. Others have negative response $85.39 \%(111 / 130)$ (Table 1$)$. 
Table 1. The result of examined serologically using CATT for Tryphanosoma evansi

\begin{tabular}{lcc}
\hline \hline Category of CATT aglutination & No. of sample & No. of dairy cattle (\%) \\
\hline Strong & 9 & 6.92 \\
Medium & 8 & 6.12 \\
Weak & 2 & 1.54 \\
Negative & 111 & 85.39 \\
\hline Total & 130 & 100 \\
\hline
\end{tabular}

Serological test with CATT - Trypanosoma evansi (\%)

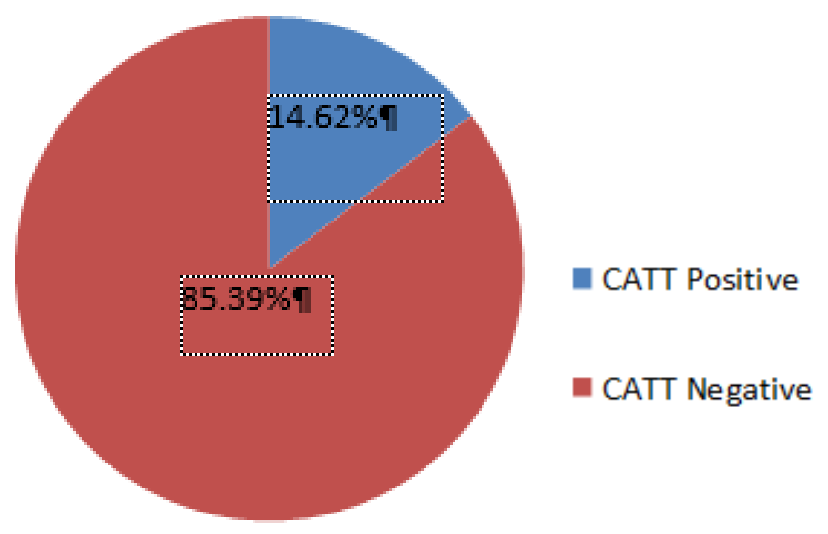

Figure 2. The results of the examination of serum dairy cattle in Cibungbulang Districts using serological tests of CATT - T. evansi

The principal serological diagnostic tests for surra disease is immune reactions between host and parasite agents. The CATT/T.evansi is a technique often used in the field. The technique is believed to be able to detect Ig M which occurs early in infection, in contrast to the ELISA technique used to detect Ig G (Aquino et al. 2010). According to Desquesnes et al. (2013) that these two techniques can be done together in order to obtain a powerful diagnostic conclusions.

Dial et al. (1994) reported prevalence of trypanosomiasis $30.6 \%$ and $5.585 \%$ based on CATT/T.evani and parasitological observation (blood smear), respectively. The technique has higher sensitivity than blood smear or MHCT. This is due to the animals that have chronic infections or have a number of parasites in the blood were very low and fluctuating, so it could not be detected by blood smear or MHCT. The advantages of agglutination test kit CATT compared with other serological tests and parasitological test is the technique can be done easily, quickly and have a high enough sensitivity and specificity of the $T$. evansi. Agglutination test principle is the bond between antigen stained with antibody homolog to form larger clumps that can be seen visually. However, the technique also has a weakness in addition to relatively high prices also their difficulty in distinguishing the product of a reaction between a weak positive to negative reactions (Rady 2008). Another disadvantage of the CATT test is the presence of cross-reactions with other antibodies of species Trypanosoma which is a major problem in a country where various species Trypanosoma often appear, such as in some African countries (Luckins 1992). However, in Indonesia is not a problem because of the presence of other species Trypanosoma is not much. T. theileri can be found in Indonesia but with CATT test does not produce cross reactions. 
Multiple parasite infestation causes higher production losses. The economic losses of dairy cattle such as reduction in milk production, inhibited body development, infertility and also predispose the metabolic diseases (Ahmad \& Gholib 2014; Munadi 2011). Mild infestation can not be directly perceived by farmers as a result, because the dairy cattle looks healthy but the milk production decreasing. If parasitic infestation is getting severe, it will cause low appetite, stunted growth and underweight. The symptoms are followed by decreasing milk production. The nutrious feed can not be absorbed by the body properly because it will absorb by worms (Nofyan et al. 2010; Nurtjahyani 2014).

The percentage of parasites infestation in dairy cattle are relatively moderate. It is due to the condition of the stables and management livestock similar and the farmers are not giving anthelmentic frequently. This is accordance with Beriajaya et al. 2006, Coles et al. 2006, and Nofyan et al. 2010 stating that farmers are commonly combating worms using drug anthelmintic incorrectly. Cattle in Cibungbulang District also have a low body condition score (BCS) because of parasites infestation, so that it cause various adverse effects such as weight loss and cause of death, especially in calves (Sutherland \& Leathwick 2011). This parasitic infection can significantly reduce the income of farmers (Regassa et al. 2006; Patra 2007).

Cibungbulang District is a center for dairy cattle as a source of milk producers for Bogor and surrounding area. The existence of positive serological reactions of $T$. evansi could lead to an adverse impact on the supply of milk and livestock conditions. This condition could be more severe if parasites disease control is not done quickly and accurately, because it is possible to have the potential spread of the vulnerable populations in other areas or to another island. Parasitic disease were given priority in the government's handling.

Improper maintenance management led to an increase in the prevalence of parasitic disease in cattle. Environmental conditions and seasons also affect the level of infestation. Humid environmental conditions support the development of gastrointestinal tract worms (Yatoo et al. 2012). This is in accordance with the opinion of Jumaldi and Wijayanti (2010), that the rainy season, high humidity and low temperature conditions is preferred by parasitic worms to thrive.

Therefore, good livestock management is needed to control the level of parasitic diseases in livestock. Improved understanding of farmers regarding parasitic diseases is necessary, so that farmers understand and aware about parasitic diseases. Anthelmentic treatment routinely, good cage hygiene, good sanitation and appropriate feeding is very helpful in controlling parasitic diseases.

\section{CONCLUSION}

The percentage of nematodes infested to dairy cattle in Cibungbulang District is relatively moderate because combating using anthelmentic by farmers is often done improperly. In addition, surra is prevalent in the area. In term of management system, farmers should mantain an environment sanitation to enhance milk production.

\section{ACKNOWLEDGEMENT}

To Mr. Eko Setyo Purwanto, Mr. Edi Satria, and Mr. Farlin Nefho from the Laboratory of Parasitology, Indonesian Research Center for Veterinary Science, for technical support with the figures. 


\section{REFERENCES}

Ahmad RZ, Gholib D. 2014. Pemberian Duddingtonia flagrans dan Saccharomyces cerevisiae meningkatkan produksi susu dan menurunkan populasi cacing pada sapi. J Vet. 15:221-229.

Agustina KK, Dharmayuda AAGO, Wirata IW. 2013. Prevalensi Toxocara vitulorum pada induk dan anak sapi Bali di wilayah Bali Timur. Bul Vet Udayana. 5:1-6.

Anderson RC. 2000. Nematode parasites of vertebrates, their development and transmission. $2^{\text {nd }}$ Ed. Wallingford Oxon (GB): CABI Publishing.

Aquino LPCT, Rosangela ZM, Karen RL, Luiz CM, Garcia MV, Gustavo PB. 2010. Antiigenic characterization of Trypanosoma evansi using sera from experimentally and naturally infected bovines, equines, dogs and coatis. Rev Bras Parasitol Vet. 19:112-118.

Beriajaya, Nurhadi A. 1995. Infeksi cacing nematoda gastrointestinalis pada domba di perkebunan karet. Majalah Parasitol Indonesia. 8:7-13.

Beriajaya, Haryuningtyas D, Husein A. 2006. Metode daya tetas telur untuk menentukan tingkat resistensi cacing nematoda pada domba dan kambing. Dalam: Mathius IW, Sendow I, Nurhayati, Murdiati TB, Thalib A, Beriajaya, Prasetyo LH, Darmono, Wina E, penyunting. Cakrawala baru IPTEK menunjang revitalisasi peternakan. prosiding seminar nasional teknologi peternakan dan veteriner. Bogor, 5-6 September 2006. Bogor (Indonesia): Puslitbangnak. hlm. 349-354.

Coles GC, Jackson F, Pomroy WE, Prichard RK, Von Samson-Himmelstjerna G, Silvestre A, Taylor MA, Vercruysse J. 2006. The detection of anthelmintic resistance in nematodes of veterinary importance. Vet Parasitol. 136:167-185.

Desquesnes M, Helzmuller P, Lai DH, Dargantes A, Lun ZR, Jittapalapong S. 2013. Trypanosoma evansi and surra: A review and perspectives on origin, history, distribution, taxonomy, morphology, hosts, and pathogenic effects. Biomed Res Int. 2013:1-22.

Dial O, Songo EB, Magnus E, Koyate B, Dallo B, Van Meirvenne N, and Hammers R. 1994. Revenue Sceintifique et.lechnique Int Epi. 13:793-800.

Handayani P, Santosa PE, Siswanto. 2015. Tingkat infestasi cacing saluran pencernaan pada sapi bali di Kecamatan Sukoharjo Kabupaten Pringsewu Provinsi Lampung. J Ilmiah Peternakan Terpadu. 3:127-133.

Jumaldi, Wijayanti A. 2010. Prevalensi dan jenis telur cacing gastrointertinal pada rusa Sambar di penangkaran rusa desa api-api Kabupaten Penajam Paser Utara. Samarinda (Indonesia): Jurusan Biologi FMIPA, Universitas Mulawarman.

Kertawirawan PA. 2013. Pengaruh tingkat sanitasi dan sistem manajemen perkandangan dalam menekan angka kasus koksidiosis pada pedet sapi Bali. Widyariset LIPI. 16:287-292.

Luckins AG, Mclntyre N, Rae P. 1992. Multiplication of Trypanosoma evansi at the site of infection in skin of rabbits and cattle. Acta Tropica. 50:19-27.

Munadi. 2011. Tingkat infeksi cacing hati kaitannya dengan kerugian ekonomi sapi potong yang disembelih di rumah potong hewan wilayah eks-kresidenan Banyumas. Agripet. 11:45-50.

Nezar MR, Susanti R, Setiati N. 2014. Jenis cacing pada feses sapi di TPA Jatibarang dan KTT Sidomulyo Desa Nongkosawit Semarang. Unnes J Life Sci. 3:93-102.

Nofyan E, Kamal M, Rosdiana I. 2010. Identitas jenis telur cacing parasit usus pada ternak sapi (Bos sp) dan kerbau (Bubalus sp) di rumah potong hewan Palembang. J Penelitian Sains. 10:611 .

Nurtjahyani SD. 2014. Prevalensi infeksi telur cacing nematoda pada feses sapi potong (Bos sp) dengan metode whitlock. Prosiding Seminar Nasional Biologi FKIP UNS. 11:539-543.

Patra AK. 2007. Nutritional management in organic livestock farming for improved ruminant health and production an overview. Livest Res Rur Develop. 19:1-21. 
Purwanta. 2012. Penyakit cacing saluran pencernaan pada sapi Bali. Gowa (Indonesia): Unit Penelitian dan Pengabdian pada Masyarakat (UPPM). Sekolah Tinggi Penyuluhan Pertanian (STTP) Gowa.

Rady AA. 2008. Epidemiological studies (parasitological, serological and molecular techniques) of Trypanosoma evansi infection in camels (Camelus dromedarius) in Egypt. Vet World. 1:325328.

Rahmi E, Hanafiah M, Sutriana A, Hambal M, Wajidi F. 2010. Insidensi nematoda gastrointestinal dan protozoa pada monyet ekor panjang (Macaca fascicularis) liar di Taman Wisata Alam (TWA) Pulau Weh Sabang. J Ilmiah Ilmu-ilmu Peternakan. 8:286-291.

Rajakaruna RS, Warnakulasooriya KN. 2011. Gastrointestinal parasites in dairy cattle in kandy district in Sri Lanka. Annual Res J SLSAJ. 11:92-99.

Regassa F, Sori T, Dhuguma R, Kirios Y. 2006. Epidemiology of gastrointestinal parasites of ruminant in Western Oromia, Ethopia. Int J Res Vet Med. 4:51-57.

Santosa S, Agus S, Ratih W. 2013.Analisis potensi pengembangan usaha peternakan sapi perah dengan menggunakan paradigma agribisnis di kecamatan musuk Kabupaten Boyolali. Bul Peternakan. 37:125-135.

Satrija F, Ridwan Y, Retnani EB. 2011. Efficacy of piperazine dihydrochlloride against Toxocara vitulorum in buffalo calves. J Vet. 12:77-82.

Soulsby EJL. 1982. Helminths, arthropods and protozoa of domesticated animals. $7^{\text {th }}$ Ed. London (UK): Bailliere Tindall.

Sudarisman. 2006. Pencegahan penyakit virus pada hewan dengan vaksin mucosal. Wartazoa 16:181-189.

Sutama IK. 2008. Pemanfaatan sumberdaya ternak lokal sebagai ternak perah mendukung peningkatan produksi susu nasional. Wartazoa. 18:208-217.

Sutherland IA, Leathwick DM. 2011. Anthelmintic resistance in nematode parasites of cattle: A global issue. Trends Parasitol. 27:176-181.

Winarso A, Satrija F, Ridwan Y. 2015. Faktor risiko dan prevalensi infeksi Toxocara vitulorum pada sapi potong di Kecamatan Kasiman, Kabupaten Bojonegoro. J Ilmu Pertanian Indonesia. 20:85-90.

Withlock JH. 1960. Diagnosis of veterinary parasitism. Philadelphia (US): Lea and Febiger.

Yatoo M, Kumar P, Dimri U, Sharma MC. 2012. Effects of climate change on animal health and diseases. Int J Livest Res. 2:15-24. 